\title{
Fairy Tale Development of Creativity Skills Basic Schools Students
}

\author{
Ismail Marzuki \\ University of Muhammadiyah Gresik, Indonesia \\ E-mail: Ismailmarzuki@umg.ac.id
}

Received: July 1, 2019 Accepted: September 17, 2019 Published: September 19, 2019

doi: 10.5296/jsss.v7i1.15006 URL: https://doi.org/10.5296/jsss.v7i1.15006

\begin{abstract}
The purpose of this study is to improve students' creative thinking skills in solving social problems proposed to them. The research design takes the form of a cycle starting from initial reflection $\rightarrow$ planning $\rightarrow$ action and observation $\rightarrow$ evaluation and reflection. If the indicator of success has not been achieved in cycle one, the researcher will conduct the second cycle with the same stage. After the data is collected the researcher will analyze the data, the technique used is descriptive quantitative data analysis techniques, namely analysis techniques by presenting data in the form of numbers or percentages to then be described. The first step of the analysis is to make a "suitable list of conformities" between the problems proposed and the answers to the research subjects. This step is to simplify the recapitulation of the answers of the research subjects between the wrong answers and the correct answers. In the list of matches, it has also been shown the category of types of creative thinking that might be given by the research subject.

The second step is to calculate the answers of respondents then classified and entered into categories so that the information is more concise and detailed. In this activity, the researcher conducted a tabulation, namely the use of tables so that the data presented were more practical and easily understood besides being more systematic and directed. Third analyzing data means that the answers of respondents are related, aligned, and compared between one another and then described.

The results showed that there was an increase in students' creative thinking skills because of the fairy tale activities carried out by researchers and there were positive responses from students to fairy-tale activities/activities carried out by researchers. The results will be disseminated at the research seminar and publish it to an accredited journal. The results seminar is expected to be a place for discussion for researchers, education practitioners, parents of students, especially teachers at the Muhammadiyah Manyar (SDMM) Gresik
\end{abstract}


Elementary School. While publication of research results is expected to be able to enrich the literature of research results, especially those relating to fairy tales and students' creative thinking skills in solving social problems.

Keywords: Creative thinkinf skills, Fairy tales

\section{Introduction}

One of the problems in learning social studies in elementary schools is the low skills of students in answering questions solving (problem-solving). As an example of the daily results of basic competencies (KD) methods for dealing with natural disasters in class VI-A of Muhammadiyah Manyar Elementary School (SDMM) Gresik in 2016/2017, only 56\% of students could answer correctly, while in VIB class there were $43 \%$. Based on discussions with the homeroom known that the causes of this problem are: 1) students are less capable identified problem presented, 2) students are less able to analyze the cause of the problem, 3) students are less able to analyze the problems in comprehensive, and 4) students have not been able to organize imagination so the answers given are very short, less extensive, and less than perfect.

At the time of the discussion, auto-critics also emerged that this low skill might be due to an inappropriate learning atmosphere such as being too tense, rigid, and unpleasant .P lots of learning is fixed on teaching material and less associated with problems around students, and less trained in problem-solving due to time constraints. Another cause of this problem is that students' creative thinking skills are still low because it is rarely trained, even though with this skill students will be able to solve various social problems they face. To this skill is a high-level thinking skill which must, therefore, be introduced and trained to students (Krulik, 1995).

Seeing the problems above, researchers and class teachers plan to jointly look for ways to overcome them. Moreover, in the 2013 curriculum, the competency of IPS has emphasized the need for students' ability to solve social problems faced. The approach to overcoming this problem according to researchers and classroom teachers is to improve the learning process from the selection of methods, the use of media, to the learning strategy process. The teacher will try to create an atmosphere of learning can be fun and encourage their students active in it as well as he practices creative thinking skills in it. This is because the purpose of IPS is to equip students so that they have the basic ability to think logically and critically so they can solve problems and be skilled in their social life .Especially in the future students will face more severe challenges because of the ever-changing and dynamic global life (Ministry of National Education, 2003).

One alternative to solving problems is fairy tales, and this is what researchers will apply. A fairy tale is an ancient Javanese tradition that is easy and inexpensive can also be done by many. The fairy tale of several articles is a story that does not really occur periodically from articles that are not real (KBBI, 1991). Other experts say that fairy tales are fiction stories / stories that are not real / fictional, such as stories of animals and inanimate objects (fables), adventure stories (sage), folktales (stories), origins (legends), stories about spirits (mite), and great stories such as in the Mahabharata, Ramayana, Saur Sepuh, Tinular Speech etc. The conclusion is a fairy tale is a story that does not really happen, does not exist and comes from 
the results of someone (Bimo, 2011). It's just that the fairy tale has its own beauty and pleasure and can carry certain missions and messages. Fairy tales are very fun especially for children, therefore fairy tales can be included as a method in the world of education (Rampan, 2012). Especially for fairytale elementary school children is the right choice because they are the ones who have great attention to stories and high imagination (Mahardika, 2015).

Musfiroh (2005) states that fairy tales have many functions, where functions can be drawn in the world of education. This function in fairy tales can help the formation of morals, the explanation is that the content of fairy-tale stories is good, so it can instill good moral values. Storytellers will explain which actions are good and can be imitated and which are bad and do not need to be imitated. Both tales can channel children's imagination needs because fairy tales are a means of channeling about the various things that arise in their minds. When listening to a fairy tale the child's imagination will be aroused and imagine what will happen to the characters in the story. This image will have a positive influence on them in solving problems creatively. Through fictional fables, children will become better, more critical, and smarter. This is, of course, different from the activities of children who watch television, because fairy tales require children to make their own visualization of what is heard, and also see the characters and stories that exist at the same time do not see children see television.

These three fairy tales can stimulate creative minds, the power of imagination in fairy tales will encourage creative minds in children. The problems presented in the fairy tale that can be solved by fairy tales will be a capital for children to solve problems. When this is often trained, the child will be able to give birth to new solutions to various problems he encounters. Fairy tales will inspire children to hear how fairy tales solve problems experienced. Musfiroh (2005) further stated that fairy tales can be an alternative medium of learning in schools. He stated that the power of fairy-tale narratives can be used to foster concentration and inspire children's imagination. Tales that are delivered verbally alone already have imaginative power, especially if the presentation is packaged more varied will certainly be more meaningful like the tales played by teachers and students can be together. The fairy tales delivered well will be remembered by students, so storytellers need to know the basics of good storytelling so that the tales can be remembered. Following this, according to Musfiroh (2005) are the basics of storytelling so that stories can be effective. 1) Storytellers need to find the right tales, namely simple tales, elements, characters, and problems. 2) Storytellers should interact with listeners because through fairy-tale interaction it will be interesting. As good as any fairy tale that is presented if it is not heard by listeners, it will be in vain. 3) Turn on characters and feelings, fairy tales will be more interesting if presented by highlighting the emotions of the characters. Listeners will feel comfortable listening to the fairy tale when the storyteller is able to display the character well. The use of sound colors, high and low tones, and rhythms also affect the quality of fairy tales. 4) Starting a fairy tale with simple sentences, such as; "In ancient times", or "reportedly said". Then stop for a moment to provide space for imagination then continue with words, sentences or movements which essentially make the listener feel amazed and interested. 5) Ending the fairy tale perfectly, try not to give additional information after you are over. Let listeners play with their imagination, imagine what they hear. 6) Starting a fairy tale calmly, effectively convey a fairy tale by removing things that are not needed. Storytellers should appear full of confidence and present fairy tales with all their 
heart.

There have been many studies that examine the fairytale connection with the formation of character, but not many have linked it with creative thinking skills. This study tries to examine the relationship between the two because creative thinking becomes something important and needed in various lines of life. This skill will make a person able to see a problem in many perspectives, thus enabling him to obtain various alternative solutions to solve it. Creative thinking according to Malaka (2011) should be not associated with ma-king things just because humans can't create new things. Saving something that a lre ady exis tse into something perfect is part of creative thinking.

Munandar (2012) revealed that "creative people are always curious, have a broad interest, and love hobbies and creative activities. Creative students are usually independent and have self-confidence because they are more willing to take risks than most children. Treffinger in Munandar (2012) says that creative individuals are usually more organized in action, because before they act they have thought through the consequences that might cause the study of creative individuals is very related to the discussion of creativity in general. Parnes (Munandar, 2012) mentions there are four aspects of creativity, namely fluency (flexibility), flexibility (flexibility), originality (authenticity), elaboration (detail), and sensitivity (sensitivity). Fluency is the ability to express ideas to solve the problem; flexibility is the ability to generate ideas to solve problems with things outside habits; originality is the ability to respond uniquely; elaboration is the ability to express ideas in detail to realize ideas into reality.

In line with Parnes, Jamaris said there were five aspects of creativity, namely: 1) fluency in providing answers, expressing ideas/opinions; 2) flexibility suggests alternative solutions problem; 3) produce ideas or works of thought own; 4) the ability to expand ideas and aspects that others don't think of, and 5) tenacity facing a situation that is not erratic (Sujiono, 2010). Departing from this, Munandar (2012) when assessing creativity is to use the four aspects of creativity above, namely: 1) fluency, 2) flexibility, 3) authenticity, and 4) detail (elaboration).

DeBono in (Mc Gregor, 2007) mentions that creative thinking skills are needed by everyone. These skills are useful for improving the quality of life, solving problems, designing things, creating changes, and increasing the effectiveness and efficiency of a system. It is no exaggeration if Alexander (2007) mentions that the success of one's life is greatly influenced by how creative it is to solve problems in life. Therefore this skill should begin to be trained from an early age, starting from the family environment, pre-school education to college, in addition to developing other aspects of intelligence.

More than that creative thinking skills are one of the skills required by the world of work. Career Center Maine Department of Labor (2004) mentions that one of the desired characteristics of the labor market is a workforce that has the ability to think creatively especially problem-solving skills (problem-solving). Departing from this statement, it is desirable that schools and educational institutions especially develop these skills so that each student has that competence. Law of the Republic of Indonesia No. 20 of 2003 concerning National Education System (National Education System) also explains that the purpose of education is to develop the potential of students to become human beings who believe and fear the Almighty God, are noble, healthy, knowledgeable, capable, creative, independent, 
and become citizens democratic and responsible.

Based on the description above, it can be seen that the function and purpose of education is a vehicle for developing students to become creative human beings, both in terms of cognitive, behavior, and attitude. Munandar (2012) mentions that the development of creativity is important because with creativity students will be able to: 1) actualize their own potential optimally, 2) see the various possibilities of solving problems faced, 3) increase the value of self-satisfaction, 4) and improve quality his life.

\section{Research Methods}

The design of this study is referring to the stages of action research, namely the existence of a cycle in research. Each cycle has three stages, namely planning $\rightarrow$ action and observation $\rightarrow$ evaluation and reflection. Before making an action plan, the first step of the researcher is to measure the extent to which students' creative thinking skills solve problems of social problems that are posed to him. The step is done by free tests (diagnostic tests) on them, as well as to measure the impact of actions researchers will also do the same thing that is conducting a test. The location of this research was at Muhammadiyah Manyar (SDMM) Gresik Elementary School.

Research variables there are two independent variables and the dependent variable. Changing free is the "fairy tale" was the dependent variable is the creative thinking skills to solve social problems. This research is action research, where the researcher will collaborate with the fifth-grade teacher of the Muhammadiyah Manyar (SDMM) Elementary School Gresik. The research was conducted with the chemistry and Taggart model cycles, with indicators of an increase in creative thinking skills in students in each evaluation.

The data of this study were obtained through observation and tests (giving assignments) during classroom learning. Observation is carried out together with the implementation of actions to collect data related to the activities and responses of students in managing learning. While the data on students' creative thinking skills are obtained through tests, namely by giving them problem-solving questions. After the data is collected the next step is data analysis. The analysis technique used is descriptive quantitative data analysis, namely analysis techniques by presenting a number of data in the form of numbers or percentages to then be described. These data are the answers to the research subject to the case/problem given by the researcher. The first step of the analysis is to make a "suitable list of conformities" between the problems proposed and the answers to the research subjects. This step is to simplify the recapitulation of the answers of the research subjects between the wrong answers and the correct answers. In the list of matches, it has also been shown the category of types of creative thinking that might be given by the research subject. This step was actually carried out by researchers when researchers compiled instruments for data collection.

The second step is to calculate the answers of the respondents then classified and entered into categories so that the information is more concise and detailed. In this activity, the researcher conducted a tabulation, namely the use of tables so that the data presented were more practical and easily understood besides being more systematic and directed. Third analyzing data means that the answers of respondents are related, aligned, and compared between one 
another and then described. Data is also presented in a graphical form so that the presentation of research results can be more easily understood. The factor investigated in this study is the students' creative thinking skills with the test sheet instrument, the indicator increases if students who have creative thinking skills in each cycle are more than the previous cycle.

\section{Research Results}

The results of this study are that there is an increase in students' creative thinking skills because of the fairytale activities conducted by researchers and there are positive responses from students to fairy tale activities/activities conducted by researchers. These results are based on research data ranging from pretest, cycle 1 test results, and cycle 2 test results. The fairytale activity was carried out regularly by researchers at one of the classes at Muhammadiyah Manyar Elementary School where tales were integrated with material on themes 2, 3 and 4. The study began in March 2018 by conducting a preliminary visit to a school. On that occasion, the researcher also introduced himself to the classroom teacher and research subject.

The next activity is conducting observation and mapping of KD (Basic Competence) with the fifth-grade teacher. A week after the observation the researchers conducted a pretest to measure the creative thinking skills of the research subjects. A pretest is done spontaneously not by doing any action before, the goal is to find out the level of students' creative thinking skills as well as the comparison material with the results of the posttest. Pretest material is social problems surrounding empathy and obligation towards friends who experience disaster. There are two pretest instruments, namely reading and questions about the contents of the reading. The focus that is to be explored is the idea of students in facing the emergency atmosphere and attitude towards friends who experience disaster. The question of pretest was done for 10 minutes by answering the two questions directly.

The pretest results are grouped into five categories whose groupings are based on students' creative thinking abilities. The categories are "very good", "good", "enough", "lacking", and "very lacking". "Very good" category is a category where students have had four creative thinking abilities, namely being able to express ideas of problem-solving (fluency), ideas put forward in a way that is unusual (flexibility), unique ideas, and elaboration. While the "good" category is a category for new students who have three creative thinking abilities, the category "enough" for students who have two creative thinking abilities, the category "less" is for new students who have one ability, and categories "very lacking" for students who do not have the ability to think creatively at all .

The pretest results show that out of 28 students, 4 students (14\%) have met the category of "very good" because they already have four creative thinking abilities, namely being able to express ideas of solving problems (fluency), ideas put forward in a way that is unusual (flexibility), the idea is unique (originality), and the ideas put forward detailed (elaboration), 5 other students in the category of "good" because it only has three ability to think creatively, 2 students categorized as "fairly new" has two abilities to think creatively, 6 students categorized as "less "I only have one creative thinking ability, and 11 students are categorized as" very lacking "or have no creative thinking skills at all.

A week after the pretest the researcher then took action by giving a tale to the subject with 
material life of the people of Indonesia in the colonial era B elanda. The content of the story is about the life of the Indonesian people is very difficult. Suffering, poverty, hunger for 350 years. Many residents die of starvation because their crops are taken by the invaders, or if they are bought at a very cheap price. The people cannot buy clothes because they do not have money even to meet food needs is very difficult. In terms of education they are also very left behind because they are not allowed to go to school. Life they are very alarming, depressing, and makes the heart seemed to cut hear his story. But in those days there were families that could still survive, namely Pak Subali's family. This family fulfills its basic food needs, occasionally they only cook leaves around their house. For their clothing needs, they wear burlap clothes (where rice containers are now) because there is nothing else. Meanwhile, to fulfill the educational needs of his son, Pak Subali told his children to recite in a mosque and kyai near a house that did not have to pay. After delivering the story the researcher held a post by giving a problem/case to resolve. The case is similar/variable the same but the setting/background is different.

The case or problem is related to the progress of the age, where this century is the millennial century marked by the advancement of information and communication technology. If there were people who died, the family sent an envoy to convey the sad news. New news for the next two or three days when the house of a family member is far away. Now that is no longer the case because if there is news of grief it can be delivered via mobile phone by a direct telephone, send SMS, or WA. In the midst of the progress of the era there was an irony, namely, the incident that happened to Pak Kambali's family, this family did not have a TV, fridge, or fan, let alone a handphone. This family is very simple and even poor, three children Mr. Kambali Umar, Purnama, and Dasmin cannot go to school, because their parents have no money. Mr. Kambali was chronically ill and was paralyzed because he could not work, to make a living, his wife had to work even if only as a washing worker. They eat once a day so much, their homes located on the edge of the village near the village fields seem to distance them from their neighbors.

The problem that must be solved by students is if you become Umar (first child) what should be done to help his mother and how. The second problem is how you can be smart while having no fees for schooling, and how. Post-test results show that of 28 students, 7 students $(25 \%)$ have met the category of "very good" because they already have four creative thinking abilities , namely being able to express ideas of solving problems (fluency), ideas put forward in a way that is unusual (flexibility), the idea is unique (originality), and the ideas put forward detailed (elaboration), four other students in the category of "good" because it only has three ability to think creatively, 2 students categorized as "fairly new" has two abilities to think creatively, 4 students categorized as "less "I only have one creative thinking ability, and 11 students are categorized as" very lacking "or have no creative thinking skills at all.

Based on the reflection from the first cycle, it is known that 4 students during the fairy tale took place less interested. They are more absorbed in their activities, therefore researchers for the second cycle of actions use media in storytelling. The media is with dolls. It is hoped that this media can attract students to listen to the tales of researchers. The second cycle posttest results showed that of 28 students, 11 students (39\%) had fulfilled the category of "very good" because they already had four creative thinking abilities namely being able to express 
ideas of solving problems (fluency), ideas put forward out of the ordinary (flexibility), unique ideas, and elaboration ideas, 4 other students were categorized as "good" because they only had three creative thinking skills , 9 new "enough" students had two creative thinking skills, 3 students "less" category has only one creative thinking ability, and 1 student is categorized as "very lacking" or has no creative thinking skills at all. When stated in the graph the results of the pretest, post-test results 1 , and posttest 2 results will appear as the following graph:

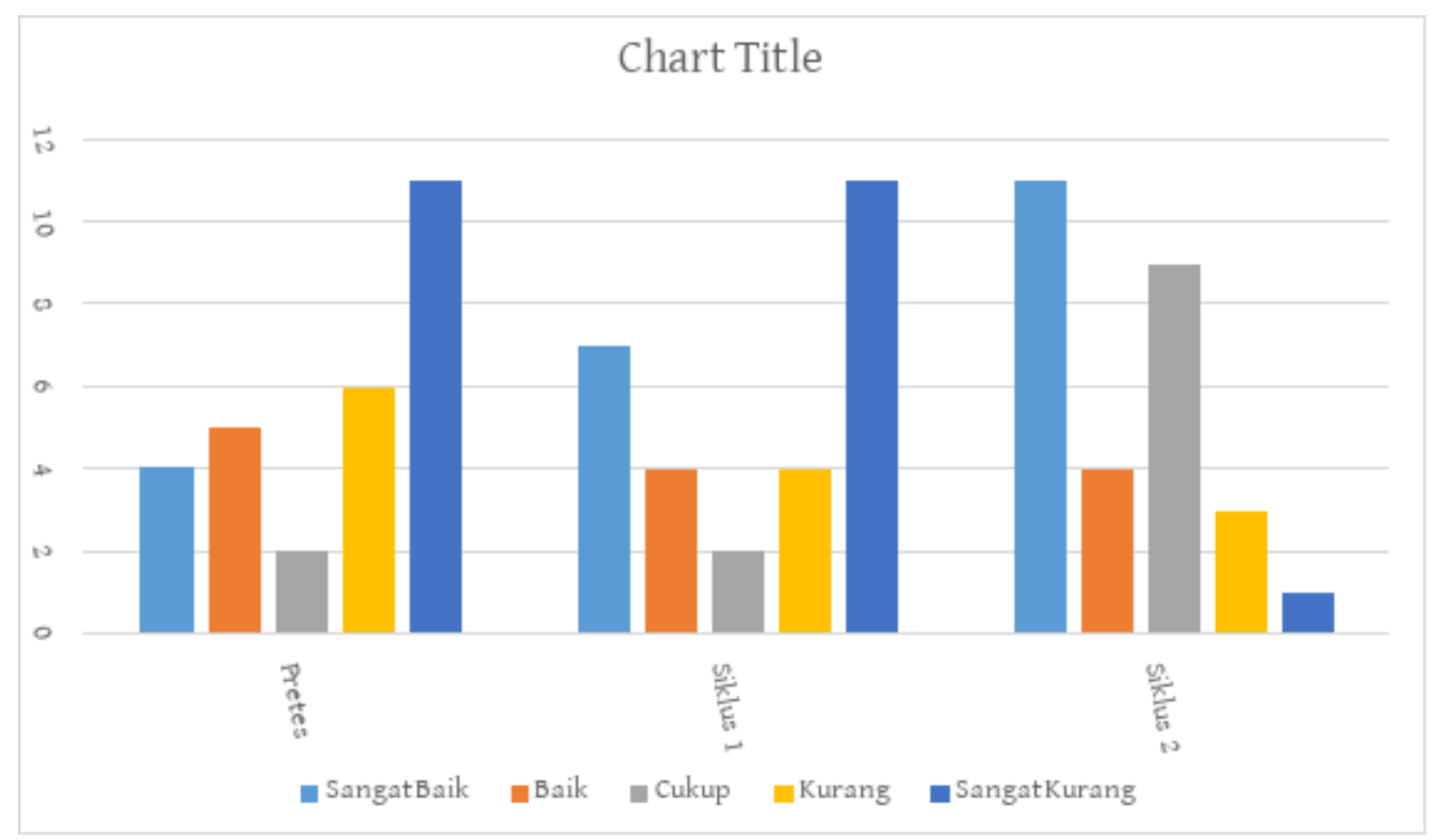

Based on the graph above, it can be seen that there is a consistent increase in students' creative thinking skills in the "very good" category. At the pretest of this category only 4 students then the number rose to 7 in the posttest cycle one and rose again to 11 students in the posttest cycle 2 . Based on these data the researcher stated that fairy tales can bring change and can improve students' creative thinking skills.

\section{Conclusion}

1) There is an increase in students' creative thinking skills because of the fairytale activities conducted by researchers.

2) Fairytale activities/activities carried out by researchers received positive responses from students.

3) Thus this study concludes that the fairy tales by teachers are able to improve the creative thinking skills of elementary school students.

\section{Suggestion}

1) Principals should motivate teachers to use fairy tales as a culture in class.

2) For teachers/homerooms, they should wish to make tales as cultures in his class.

3) For parents, it is expected that together the school can improve the creative thinking skills of their children through storytelling at home. 


\section{References}

Cognition, Creativity, and Satisfaction among Ninth Grade Students in an Introduction to World Agricultural Science and Technology Course. Disertasi pada Texas Tech University.

Career Center Maine Department of Labor. (2001). Today's Work Competence in Maine.

Kak, B. (2011). Mahir Mendongeng. Yogyakarta: Pro-U Media.

Mahardika. (2005). Jurnal Pendidikan Dasar Universitas Negeri Surabaya, 6(2).

Malaka, S. (2011). 99 Tips Cerdas dan Efektif Berpikir Positif dan Berjiwa Besar. Yogyakarta: Araska.

Mann, E. L. (2005). Mathematical Creativity and School Mathematics: Indicators of Mathematical Creativity in Middle School Students. The Disertasi University of Connecticut. Retrieved from http://www.gifted.uconn.edu/siegle/Dissertations/Eric\%20Mann

Musfiroh, T. (2005). Bercerita Untuk Anak Usia Dini. Jakarta: Departemen Pendidikan Nasional Dirjen Dikti. Depdikbud. 1991. Kamus Besar Bahasa Indonesia. Jakarta: Balai Pustaka.

Munandar, U. (2012). Pengembangan Kreativitas Anak Berbakat. Jakarta: PT Rineka Cipta.

McGregor, D. (2007). Developing Thinking Developing Learning. Poland: Open University Press.

Rampan, K. (2012). Kreatif Menulis Cerita Anak. Bandung: Nuansa.

Suharsimi, A. D. K. K. (2012). Penelitian Tindakan Kelas. Jakarta: Bumi Aksara.

Undang-Undang Republik Indonesia. No. 20 Tahun 2003 tentang Sistem Pendidikan Nasional (Sisdiknas) (2003). Departemen Pendidikan Nasional.

\section{Copyright Disclaimer}

Copyright for this article is retained by the author(s), with first publication rights granted to the journal.

This is an open-access article distributed under the terms and conditions of the Creative Commons Attribution license (http://creativecommons.org/licenses/by/3.0/). 